\title{
The sentinel over Canberra's military history: Some parishioners of St John's commemorated on the ACT Memorial
}

MICHAEL HALL

In 1912 the author Miles Franklin, the self-styled literary bishop of Monaro, who was then living in Chicago, United States of America, visited the office of the architect Walter Burley Griffin. Griffin had been announced as the winner of the international design competition for the federal capital of Australia and he had in his office a cyclorama and maps of the Canberra site that had been sent to competitors. 'It made me homesick', she wrote to her aunt, Annie Franklin, 'to see the spire of the little old church where poor Parson Smith held out so long'.

The 'little old church' was the Anglican Church of St John the Baptist, which has served the people of the Canberra district since it was consecrated in 1845. Together with its churchyard and the nearby schoolhouse, St John's reflects the evolving story of Canberra over the last 175 years, and among the elements of that story is the role that hundreds of people living within the church's parish have played in the various wars and military engagements involving Australia. Some of them are connected to Canberra and St John's from the mid-nineteenth century. Others came to help build the new city after the site was chosen in 1908 , or were transferred with the public service, fulfilling in part Canberra's destiny as the national capital. ${ }^{2}$ Their military service is commemorated on the ACT Memorial on London Circuit, and on various plaques, honour rolls and graves in the St John's precinct. ${ }^{3}$

On Wednesday 12 March 1845 the church was dedicated as the 'Church of Saint John the Baptist at Canberry. ${ }^{4}$ By coincidence, it was on Wednesday 12 March 1913 that 'Canberra' was named as the federal capital of Australia in a ceremony on Kurrajong Hill, across the Molonglo River from the church. It was Franklin's

\footnotetext{
1 Daily Telegraph (Sydney), 3 August 1912, 15. Miles Franklin quotation courtesy of Ross Maxwell, greatgrandson of Annie Franklin. The spire was completed in 1877, two years before the birth of Franklin.

2 The Seat of Government Act 1908 passed federal parliament in December 1908.

3 ACT Memorial website: www.memorial.act.govau. To be eligible for the ACT Memorial an individual had to be associated with what is now the ACT prior to service. Some of the people commemorated at St John's arrived in the ACT after their war service and are not on the ACT Memorial.

4 A. H. Body, Firm Still You Stand: The Anglican Church of St John the Baptist, Its Parish and Parishioners, 1841-1984 (Canberra: St John's Parish Council, 1986), 14.
} 
'Parson Smith', the Reverend Pierce Galliard Smith, who is as responsible as anyone for the spelling of Canberra as it was he who first began using it in parish registers and in correspondence from around $1856 .{ }^{5}$ It was also Parson Smith who conducted the funeral service for Fred Young at St John's in October 1900, the first known casualty of a war involving someone from Canberra.

\section{Fred Young}

William Frederick Young, or 'Fred', as he was known, was born on 29 June 1877 at Round Hill (Mount Painter) near the contemporary suburbs of Cook and Aranda. The family property, now known as Glenloch, was on the northern edge of the current National Arboretum and adjoined the selection of his grandfather James Young, a former convict who was transported to Australia in $1836 .{ }^{6}$ Fred's father, William Young, married Bridget Grady at St John's in 1871, part of the long association of the Young family with the church. Fred was baptised there and both his father and grandfather served for years as churchwardens at St John's.

A dispute between William Young and his neighbour, Frederick Campbell of Yarralumla, over fencing and access to a road resulted in a lawsuit in 1882 and the forced sale of the Young property. ${ }^{8}$ When his father died in 1894, the 16-yearold Fred became the family breadwinner. Eventually the family moved to a rented house near St John's, which, ironically, was on the Campbell-owned Duntroon. Fred volunteered with the New South Wales (NSW) Bushmen's Contingent in December 1899 and sailed for South Africa the following month. He served as a Trooper in D Squadron of the 1st NSW Mounted Rifles and saw action in March that year fighting the Boers at Poplar Grove, Orange Free State, and four days later at Driefontein. After a week of forced marches on limited food and water, the British forces entered Bloemfontein, the Orange Free State capital, where enteric fever was rife. There Young, who had been slightly wounded in the earlier fighting, became an unfortunate victim of the disease. He was repatriated to Australia and admitted to St Vincent's Hospital in Sydney in August 1900.

\footnotetext{
5 Body, Firm Still You Stand, 41.

6 James Young was assigned to James Wright of Lanyon in 1836 and moved to Cuppacumbalong with him in about 1848. He and his wife Margaret had a least 60 grandchildren, one of whom was Ethel 'Effie' Clara Young (born 1894, Narranderra, New South Wales), a cousin of Fred Young. She married the war historian Charles Bean in 1921 and they lived at Tuggeranong until 1925.

7 Body, Firm Still You Stand, 86.

8 Queanbeyan Age, 14 April 1882, 2. There were other fights in the region between the free selectors and the large landowners (e.g. Gribble vs Crace in 1885, see Sydney Morning Herald, 19 March 1885, 5; 27 April 1885, 4; 5 May 1885, 4; 19 February 1886, 4; Queanbeyan Age, 23 February 1886, 2).
} 
Although it seemed for a while that he might recover, Young died from enteric fever at St Vincent's on 4 October 1900. His body was returned by train to Queanbeyan where the cortege, accompanied by the mayor and aldermen, proceeded through the town and then on to St John's. A distressed Bridget Young fainted during the funeral. ${ }^{9}$ Parson Smith would soon come to understand her grief.

\section{Bradshaw and Pierce Smith}

Pierce Galliard Smith served as incumbent at St John's from June 1855 until November 1905. He arrived from Britain with his wife Emily and their two eldest children, only a few weeks before assuming his role at Canberra, where four more children would be born, including a second son, William Bradshaw Smith, usually referred to as 'Bradshaw' or 'Brad', who was born on 3 December 1862. Described by a visitor in 1872 as a 'young ruffian of some 9 summers old' who could 'make himself very agreeable but also to the contrary', Bradshaw, like his older brother Pierce, was the cause of much consternation to Parson Smith. ${ }^{10}$ The Smith boys were adventurers, sometimes broke, and they frequently asked their staid and frugal father for financial assistance.

At least Parson Smith's eldest son seemed to have prospects. Christened Pierce Eaglesfield Smith, he was born on 14 May 1853 at Featherstone Castle in Northumberland, England, where his father was then the chaplain. Pierce left Canberra at the age of 19 for the Gulf country in north Queensland where, 10 years later, he was in partnership with members of the de Salis family at Savannah Downs on the Flinders River. The de Salis's owned Cuppacumbalong near Tharwa, part of the parish of St John's, but also held extensive pastoral leases in Queensland. In 1878 the families were connected by marriage when Mary Smith, the second daughter of Parson Smith, wed George de Salis at St John's.

After finishing his schooling, Bradshaw joined his brother at Savannah Downs, later writing to his father: 'I have worked harder here than I have ever done or will ever do again for anyone'. He did not stay long, travelling and working throughout the north and trying his hand at prospecting in the East Kimberley goldfields in Western Australia. Like most prospectors Smith did not enjoy much success, but with the misplaced optimism commonly found on goldfields, Bradshaw thought: 'I think I can see the way to make a good thing out here.'

9 Queanbeyan Age, 10 October 1900, 2.

10 Body, Firm Still You Stand, 52 (observation by Rev. Stanley Howard in 1872).

11 P. Wardle, Some New Light on the Rev. Pierce Galliard Smith as Revealed by the De Salis Letters (Canberra: Canberra \& District Historical Society research paper, 1960), 27-8. 
The de Salis family lost their pastoral interests in Queensland, as well as Cuppacumbalong, in the economic depression and drought of the early 1890s. Pierce Smith found work in Queensland until enlisting with the NSW Imperial Bushmen in March 1900. He left the following month for South Africa to fight the Boers but by September his family had received news that he was to be invalided home. It was only a few months before he found a position as manager of Hodgson Downs, in the Roper River region of the Northern Territory. ${ }^{12}$ After seriously injuring his leg in a riding accident, he endured a 300-mile journey for medical treatment, but by then the wound had turned septic and his leg had to be amputated. Eventually he recovered, married in 1907 and bought a property at Oldbury near Sutton Forest, in the southern highlands of NSW, where he died on 14 July 1914.

Bradshaw meanwhile had drifted through various jobs in northern Australia in the 1890s when, in 1899, after again requesting money from his father, he tried his luck in the New Guinea goldfields. Failing to make his fortune there, he returned to Canberra in late 1900, ostensibly to recover from a bout of malaria, but his restless character meant that he did not stay for long. In January 1901 he enlisted with the 2nd Scottish Horse in Victoria and sailed for South Africa soon afterwards. An experienced bushman and confident horseman, Smith was well-suited to fighting on the high veldt. He quickly rose to the rank of sergeant in his regiment, a part of Colonel Benson's No. 3 flying column. As they returned to camp on 30 October 1901, the Boers attacked the guns at the rear of the column at Bakenlaagte, near Bethal in Transvaal.

Smith's squadron of Scottish Horse had just gained the edge of a ridge to defend the guns when the Boers charged. Most of the defenders were killed but the survivors stubbornly held on and enabled the column to escape. Smith was found dead, and was buried where he fell on the battlefield. ${ }^{13}$ In 1903 a memorial tablet, designed by his mother Emily, was placed inside St John's Church. ${ }^{14}$

\section{Eric de Salis}

Parson Smith and his wife lost not only a son to war; they also lost a grandson, Eric de Salis. Baptised Charles Eric Fabius Fane de Salis by his grandfather three months after his birth on 4 May 1891 at Cuppacumbalong, Eric was the youngest child of George and Mary de Salis. After the de Salis family sold Cuppacumbalong, they moved a few kilometres down the Murrumbidgee River to Lambrigg, the home of

12 Pierce Smith was a neighbour of Aeneas Gunn and his wife Jeanne, author of We of the Never Never.

13 Queanbeyan Observer, 24 January 1902, 2.

14 Body, Firm Still You Stand, 71. 
George's sister, Nina, and her husband, William Farrer, who were not only Eric's aunt and uncle but also his godparents. They lived there until 1900 when his father bought Soglio, a property near Michelago.

De Salis enlisted in the light horse on 20 August 1915 at Holsworthy near Sydney and joined the 2nd Light Horse Brigade Machine Gun Squadron in Egypt the following year. The machine gun squadrons provided support for the light horse and would move rapidly into position, unload their guns from their packhorses, assemble them and open fire as quickly as possible. Through late 1916 and early 1917 the light horsemen fought in an oasis-by-oasis advance, through the desert of the Sinai, to Palestine-their progress was determined by access to water as much as Turkish resistance. After the charge of the light horse secured Beersheba on 31 October, the next task was to clear the Turks from the hills to the north around Tel el Khuweilfe, a prominent position with more precious water. An attack there by British infantry and the Imperial Camel Corps on 6 November had stalled, and their position had become precarious when de Salis's squadron entered the fray.

'They charged in a very gallant manner', according to the official war history, 'and at once came under a murderous machine-gun and shrapnel fire.' They rushed their guns up the hill to within 40 yards of the Turks, and 'although the teams were shot down almost to a man, their very gallant action caused the Turks to pause and gave the 3rd (Camel) Battalion breathing-time to size up their position'. ${ }^{15}$ It was Melbourne Cup Day, and de Salis and a mate were discussing the race as they galloped into action. They had mounted their gun and commenced firing when de Salis was mortally wounded. He died at a casualty clearing station and was buried nearby, although the gravesite is unknown. De Salis was posthumously awarded the Military Medal and is commemorated at the Jerusalem War Cemetery in Israel.

\section{Ernie and Charlie Mayo}

The parish records of St John's show that the second marriage at the church was that of Alfred and Mary Ann Mayo in 1846. Among their many descendants who served in armed conflicts were two of their grandsons, Ernie and Charlie Mayo. ${ }^{16}$ Ernest 'Ernie' Frederick Mayo was born on 8 April 1888 in Queanbeyan, youngest son of John and Wilhemina Mayo. His father worked for the Campbells on various

15 H. S. Gullett, Official History of Australia in the War of 1914-18, vol. 7, Sinai and Palestine (Sydney: Angus \& Robertson, 1936), 423. Gullett's son bought Lambrigg in 1949 and it is currently owned by the family. The property was a wedding gift from Leopold Fane de Salis of Cuppacumbalong to his daughter Nina when she wed William Farrer in 1882.

16 The history of war service by descendants of Alfred and Mary Mayo extends six generations to Blaine Diddams MG (born in Canberra, 16 December 1971). Diddams, a member of the Special Air Service Regiment, died from wounds on 2 July 2012 in Afghanistan. 
properties at Duntroon, Rob Roy and Tharwa, but after he died in 1903, his widow and youngest children, including Ernie, lived in the disused schoolhouse next to St John's, before moving to Queanbeyan. ${ }^{17}$

Mayo worked as a labourer before the war and enlisted at Liverpool near Sydney on 29 October 1914, embarking for Egypt just before Christmas that year with the 13th Battalion. He landed at Gallipoli late on 25 April and the following morning his company was ordered up to what became known as Quinn's Post, the most precarious of the positions held by the Anzacs. Here the Turks were barely 40 yards away and could easily throw grenades into the Australians trenches. Mayo was twice wounded by shrapnel within the first week and was evacuated for treatment.

While convalescing in Egypt he wrote home about the landing at Gallipoli:

'It was terrible to see our comrades getting shot in the boats', he said, 'but heedless of it all our boys kept on pushing forward till they got a firm footing on shore. It seemed a relief when the shells from our gun boats started screeching overhead in reply to the enemy's land batteries. I have often wished to see naval guns in action, so my wish has been gratified at last.' ${ }^{18}$

He returned to Gallipoli in August when his battalion twice charged at the Turkish trenches on Hill 60 without success. It was part of a final failed attempt by the British forces to break the stalemate on Gallipoli.

After the evacuation from Gallipoli and further training in Egypt, Mayo and the 13th Battalion (by then part of the 4th Division of the Australian Imperial Force) was sent to France. In August 1916 the 4th Division fought at Pozières, attempting to force their way a few hundred metres to the heavily fortified and bunkered Mouquet Farm. In a 10-day tour it took six successive night attacks to get within striking distance of the farm before, exhausted and battered by constant German shelling, they were relieved. By the end of the month Mayo had been promoted to corporal and the 13th Battalion were back for another, ultimately unsuccessful, crack at 'Moo Cow' Farm.

In February 1917, at the end of a cold winter on the Somme, the Germans began retreating to their heavily fortified Hindenburg Line. The 4th Division was ordered to capture the village of Bullecourt but there the Hindenburg Line was protected by several widely spaced double belts of barbed wire, designed to channel attacking troops towards the German machine guns. Usually the attacking infantry would be supported by artillery, but at Bullecourt the Australians would, for the first time, go into battle with tanks.

17 Hope Hewitt, Canberra's First Schoolhouse: A Social History of Canberra's First School, Now St John's Schoolhouse Museum, 1845-1986 (Canberra: Schoolhouse Museum Board of Management, 1987), 94.

18 Queanbeyan Age, 13 July 1915, 2. 
The first attack was aborted when the tanks failed to arrive and a second attempt was ordered for the following day, 11 April 1917. Mayo, who by then had been promoted to sergeant, and the other men of the 13th Battalion lay out on the snowcovered ground before dawn, awaiting the tanks. Several of them arrived, but late, and even then they moved so slowly that the troops outpaced them. Against all odds, the 4th Division broke into the German trenches and may have held their position with artillery support, but none was forthcoming. The Germans counter-attacked and by noon the men of the 13th Battalion were faced with a horrendous choice. Captain Harry Murray, who had earned the Victoria Cross two months earlier, ordered a retirement. 'To the left', Murray said, 'there are two things now-capture or go into that.' 'That' was a 'hail of bullets from 4,000 rifles and 15 machine guns'.

Ernie Mayo did not make it back. ${ }^{19}$ His body was never found. The following month the 2nd Division of the AIF launched an attack on Bullecourt, this time with artillery support, and managed to hold its gains. German counter-attacks drew in the 1st Division and then the 5th Division to which Ernie's older brother, John Charles Mayo (known as 'Charlie'), belonged. He had been born on 28 January 1881 in Canberra and, like his parents and grandparents, Charlie was married at St John's Church; on 15 February 1905 he wed Florence Roberts-one of the last weddings celebrated by Parson Smith before his retirement. Although he worked for the Campbells at Duntroon, Mayo moved to Cuppacumbalong when that property was bought by George Circuitt and his partners. When Cuppacumbalong was sold in 1912, Circuitt purchased Uabba station near Lake Cargellico in western New South Wales and Mayo and his family moved with him.

He enlisted on 2 December 1915 at Cootamundra and embarked for Egypt as a private with the 17th reinforcements to the 2nd Battalion. After the Gallipoli campaign the AIF underwent a reorganisation in Egypt and Mayo was transferred to the 54th Battalion, which he joined in France in August 1916 after it had been decimated at Fromelles. Like his brother, he spent the winter of 1916-17 in the trenches of the Somme near Flers. In May 1917 he found himself on the battlefield at Bullecourt. On the morning of 15 May the Germans attacked the 54th Battalion's position in force; although the Australians repelled them, their casualties were severe. Mayo had nearly finished bandaging the head of a mate wounded during the German assault when a bomb landed between them and exploded, killing them both. They were buried where they fell and, as it was with his brother, Mayo's body was not recovered. He and Ernie are commemorated on the roll of honour on the north wall of St John's. ${ }^{20}$

19 Thomas A. White, The History of the Thirteenth Battalion, AIF (Sydney: Tyrells Ltd for 13th Battalion AIF Committee, 1924), 97.

20 The Mayo brothers are also commemorated on the Australian National Memorial at Villers-Bretonneux in France. 


\section{Ern Murray}

A headstone in the churchyard at St John's tells us that 'An Anzac Rests Here'. It is the grave of Ernest (Ern) Murray who landed at Gallipoli with the first Australians at dawn on 25 April 1915. He was born on 1 December 1880 at Surry Hills, Sydney, although he grew up on the Monaro at Cowra Creek and Michelago where his father, John, operated goldmines. By then his mother had died and his father had married May Cade, daughter of the Michelago policeman. From an early age Ern worked with his father, learning about mining and the operation of machinery. In 1909 John moved his family to Canberra where he hoped to gain construction contracts, but when they did not eventuate he opened a bakery and general store close to St John's, which became their church. May Murray was treasurer and secretary to the Parish Council before the war and organist for many years. ${ }^{21}$

Shortly after helping his father establish himself, Murray left Canberra to work at a mine near Adaminaby. There he met Ruby Monaghan, who thought that he was different from the other miners because he attended church and did not drink at the dances. They married in Sydney in September 1914. By then Murray had found work as an engineer's mechanic at the Royal Military College, Duntroon, and, following the declaration of war in August 1914, had enlisted in Sydney. He was allocated to the 1st Field Company Engineers and sailed for Egypt a month after his wedding.

The first Australians to land at Gallipoli belonged to the 3rd Infantry Brigade, but they were supported by the 1st Field Company Engineers whose job it was to cut barbed wire, demolish Turkish defences and disable enemy artillery. Murray was aboard the HMS Queen with the infantry as they sailed toward Gallipoli on the night of 24 April 1915. Like many soldiers he kept a diary in which he recorded the events of that night:

Left 'Queen' at 1.30am with destroyer towing (the four boats with troops). Landed at $4.30 \mathrm{am}$ amid a perfect hell of lead fired when we were 200 yards away and we charged through until we were only 10 yards away from the enemy. Infantry charged magnificently $\&$ drove the Turks back over 1 mile by midday. Shrapnel on landing $\&$ heavy firing continued all day, but the operations were carried out splendidly. ${ }^{22}$

At Gallipoli, Murray worked on building observation posts, machine gun emplacements and trenches, and his mining skills were employed on tunnelling towards the Turkish positions to advance the Anzac's front line. Tunnels also had a defensive role. In July, Murray supervised a fatigue party of infantry digging from

21 Body, Firm Still You Stand, 113. The site of Murray's bakery is commemorated by a plaque in Commonwealth Park.

22 James Murray, Canberra's First ANZAC: Ernest Murray 1880-1935 (Yeppoon, Qld: The Author, 2002), 30. 
Steele's Post when they detonated a mine and destroyed the enemy's tunnels near German Officers Trench. ${ }^{23}$ After the evacuation in December 1915, Murray was transferred to the newly created 14th Field Company Engineers. He fought on the Western Front at Fromelles in July 1916 and, later that year, at Flers on the Somme, he pegged out and supervised construction of jumping-off trenches for an attack on The Maze. In April 1917 Murray defused two mines under a house at Doignies left there by the Germans as a booby trap. For these actions he was mentioned in despatches. His courage and contempt for danger saw him awarded the Military Medal at Polygon Wood in September 1917 and, a month later, a bar to the Military Medal for rescuing six men wounded in a German artillery barrage near Westhoek in Belgium. He was wounded in a mustard gas attack the following January, evacuated to England and eventually returned to Australia in September 1918.

After the war Murray was granted leases to two soldier settler blocks in the Narrabundah area, which he and Ruby called Kurrumbene. His wife had grown up on the land and together they turned their property into a productive farm. Yet like many of the soldier settlers in the Australian Capital Territory, Murray struggled during the Great Depression to pay the rent on his leases and to make ends meet. ${ }^{24}$ He was still suffering health effects from the war and began making regular visits to hospital in Sydney to receive treatment for leukaemia. He died from the disease on 28 July 1935.

\section{Fred Ward}

In September 1915 Major General Sir William Bridges, founder and first commandant of the Royal Military College at Duntroon and commander of the 1st Division of the AIF, was buried in a grave on the slopes of Mount Pleasant after a funeral service at St John's. While in Canberra, Bridges and his wife Edith had been parishioners at St John's and had become friends with the rector, Fred Ward. As her husband's body was laid to rest, Lady Bridges turned to Ward and told him: 'It is your turn now'. ${ }^{25}$ Ward enlisted a month later.

Frederick Greenfield Ward was born at Acton, England, on 10 January 1876. He came to Australia around the turn of the century as a lay reader in the Anglican diocese of North Queensland at the suggestion of Bishop Christopher Barlow. His older brother, John, was already working there as a curate. After studying at

23 Murray, Canberra's First ANZAC, 32.

24 Susan Pfanner, 'Soldier Settlement Subdivisions in the Federal Capital Territory after World War I', Canberra Historical Journal, no. 37 (March 1996): 25-34.

25 Simon Ward, grandson of Frederick Ward, personal communication. 
a theological college in Brisbane, he followed Bishop Barlow and his brother to the diocese of Goulburn in 1904, was ordained a priest in 1907 and served in parishes in the Riverina until becoming the incumbent at St John's in $1913 .{ }^{26}$

Ward sailed from Sydney in November 1915 as a chaplain, with the rank of captain, attached to the 30th Battalion Headquarters, arriving in Egypt the following month. He was transferred to the 32nd Battalion in March the next year and began ministering at 'Duntroon Plateau', a sandy hill near the Suez Canal. When the 32nd Battalion was sent to France with the 8th Brigade in June 1916, Ward went with them. The brigade was decimated at the Battle of Fromelles in northern France in July 1916, and Ward had to deal with the trauma suffered by the survivors.

During the bitterly cold winter of 1916-17 on the Somme, Ward's capabilities came to the fore. The 8th Brigade occupied trenches near Flers and Ward established a soup kitchen at Waterlot Farm, just behind the front line. He was commended for his 'cheerful disposition', despite the death and carnage around him, as he dispensed hot soup and cocoa to troops returning from the trenches. To distract the soldiers he organised (and participated in) snowball fights and concerts and visited the men in the trenches where he would conduct sermons. He closely followed the 8th Brigade with his soup kitchen, setting it up at Delville Wood in February 1917 and then, after the 8th Brigade captured Bapaume, moved it to the eastern edge of the town, where he operated it while under constant artillery fire from the Germans. When the brigade advanced eastwards to Beugny, Ward soon followed and, although he was forced to evacuate after the village was heavily shelled, within minutes of the bombardment ceasing he was back at his post providing hot soup to the soldiers. Ward 'knows that a good feed does more than a sermon at times', wrote one man, 'and when he speaks they listen'. ${ }^{27}$ For his work on the Somme, Ward was mentioned in despatches and awarded the Military Cross.

In May 1917 he was evacuated to England for treatment of varicose veins. It was recommended that he return to Australia to recover, which he did in November 1917, but a further medical examination found him unfit for service and he was discharged on 2 January 1918 . He travelled to New Zealand shortly afterwards and married Braidwood-born Margery Towle in Auckland on 28 January 1918. The couple returned to Canberra where he resumed his duties at St John's. Over the next few years, two sons were born in Canberra before the family left Australia for England in 1929. ${ }^{28}$ Ward served as the incumbent at Brockham Green (1929-36),

\footnotetext{
26 Body, Firm Still You Stand, 110.

27 Queanbeyan Age, 1 February 1918, 2.

28 Ward's eldest son, Edwin 'Ted' James Greenfield Ward (born in Canberra, 16 October 1919), was appointed chaplain of the Royal Chapel in Windsor in 1955 and, although his appointment there ended in 1967, he remained a chaplain to the Queen until his death on 22 November 2005. Simon Ward, son of the Venerable Ted Ward, personal communication.
} 
Docking in Norfolk (1936-50) and finally as curate-in-charge sequestration at Bagthorpe near Norwich until his retirement in 1956. He died at Norwich Hospital on 7 February 1963.

\section{Stan Atkinson}

The 3rd Battalion played a significant part in local history during World War II as it had become, before the war, a militia unit headquartered in Canberra. Known as the Werriwa Regiment (after the Ngunnawal name for Lake George), hundreds of local men trained with the 3rd Battalion and served in the war either with it or with other military units. Among them was Stan Atkinson.

William John Stanley Atkinson was born at Skipton in rural Victoria on 7 December 1910 and joined the Postmaster-General's Department in 1925 as a telegraph messenger, before transferring to Canberra in 1928 as a clerk in the public service. He married Elizabeth (Betty) Arnott at Queanbeyan on 24 October 1930 and they lived at Braddon. An accomplished singer and theatrical performer with the Canberra Amateur Operatic Society, Atkinson was also a prominent Australian Rules footballer in the 1930s, winning premierships with both the Acton and Ainslie clubs. He enlisted in the militia in Canberra in January 1937 and was appointed lieutenant in the 3rd Battalion on 10 February 1939. By the time he was mobilised in October 1940, he had been promoted temporary captain.

After the Japanese landed near Lae, New Guinea, in March 1942, the 3rd Battalion was sent to reinforce Port Moresby. Atkinson became commanding officer of the 3rd Battalion's B Company, leading them two months later onto the Kokoda track. On 18 October 1942 the 3rd Battalion attacked the Japanese at Templeton's Crossing high in the Owen Stanley Ranges. As Atkinson attempted to bandage one of his men who had been wounded in the chest, a sniper shot at him, the bullet passing between his back and his pack, hitting his dixie. He urged the remainder of his men forward and they began 'yelling and whooping' as they charged 'headlong over vines and logs and through scrub with guns blazing and mortars exploding'. They routed an enemy twice their number and captured a headquarters area where they found food, equipment and documents. After the battle Atkinson was heard singing. 'I knew he had a fine baritone voice from his Canberra days', recalled one of his men, 'and it was as pleasing to hear as it was unexpected. ${ }^{29}$ For his inspiring leadership and personal bravery, Atkinson was awarded the Military Cross.

29 Colin Kennedy, Port Moresby to Gona Beach: 3rd Australian Infantry Battalion 1942 (Turner, ACT: C. Kennedy, 1992), 97. 
He led his men throughout the Kokoda campaign and on towards Gona on the north coast of Papua, but became ill with malaria and returned to Australia in January 1943. Transferred to the 2/4th Battalion in July 1943, he served on the north coast of New Guinea from November 1944 in the campaign against the Japanese near Wewak and the Prince Alexander Ranges until July 1945 when he was attached to headquarters in Lae.

Atkinson worked for the Department of External Affairs after the war and served as treasurer at St John's (1951-57). In 1960 he was licensed as a deacon in the church and then was ordained as an Anglican priest at St John's on 21 September 1962. An appointment followed to St Philip's Church, O'Connor, where he ministered until 1964. He also served with the church at Delegate (1964-66), Canterbury (1966-67) and Torrens (1967-76) until he retired in August 1976. Atkinson died on 7 October 1996, aged 85 years, and his ashes were interred in the columbarium in St John's churchyard.

\section{The sentinel}

The church's military connection began with the arrival of the Royal Military College at Duntroon in 1911. The incumbent of St John's, Rev. Arthur Champion, was appointed Honorary Chaplain to the college and he conducted the first Anglican service there shortly after the first cadets were attested in June that year. ${ }^{30}$ Sixty per cent of former cadets and staff at the Royal Military College who enlisted in World War I were Anglican and regularly attended services at St John's. ${ }^{31}$ There are numerous windows and plaques on the walls of the church commemorating former parishioners, and the original regimental colours for the Royal Military College and the 3rd Battalion hang from the gallery balustrade.

After Charles Campbell, a pilot with the Royal Flying Corps, was shot down over France and killed in 1917, his father, Frederick Campbell, the nemesis of William Young, had a stained-glass window installed in the church. William Bridges is also commemorated by a plaque in the church, as is Eric de Salis. On an outside wall is an honour roll of 60 parishioners who died in the Great War and in the churchyard are the graves of more than 40 returned servicemen from that conflict. Fred Ward donated two lanceolate windows made from fragments of stained glass

30 Body, Firm Still You Stand, 105. Champion, rector at St John's from 1909 to 1913, lost two sons in World War I. 31 Michael Hall, 'The ACT Memorial and the First World War', Canberra Historical Journal, no. 78 (March 2017): 6 . 
he collected from ruined churches on the Western Front, and the names of several hundred parishioners who served in World War II are recorded in a hand-printed remembrance book kept in a shrine inside the church. ${ }^{32}$

In 2006 the ACT Memorial was dedicated in a ceremony at Ainslie Place in Civic. Along with an online database, the memorial commemorates the men and women from the Australian Capital Territory who have served in wars and on humanitarian and peacekeeping missions. Yet tucked away in a small, often unnoticed corner of the city is St John's, standing 'like a sentinel' over so much of Canberra's history. ${ }^{33}$ With its tangible reminders of the cost of war it is, nonetheless, a peaceful place in which to contemplate the sacrifice and service of its parishioners in conflicts around the world.

32 The remembrance book was donated in memory of Sir Cyril Brudenell White, Bridges's chief of staff, who died in 1940 when his aeroplane crashed near Canberra airport. He was Chief of the General Staff at the time of the crash on 13 August 1940. H. S. Gullett also died in the accident.

33 Body, Firm Still You Stand, 103; from a poem about St John's by Rev. Arthur Hopcraft (1906). 
This text is taken from Australian Journal of Biography and History: No. 2, 2019, published 2019 by ANU Press, The Australian National University, Canberra, Australia.

doi.org/10.22459/AJBH.2019.06 